\title{
Sex Manuals in Malay Manuscripts as Another Transcript of Gender Relations
}

\author{
Maznah Mohamad
}

check for updates

Citation: Mohamad, Maznah. 2021. Sex Manuals in Malay Manuscripts as Another Transcript of Gender Relations. Religions 12: 368. https:// doi.org/10.3390/rel12050368

Academic Editors: Terence Lovat and Susanne Olsson

Received: 19 March 2021

Accepted: 17 May 2021

Published: 20 May 2021

Publisher's Note: MDPI stays neutral with regard to jurisdictional claims in published maps and institutional affiliations.

Copyright: (c) 2021 by the author Licensee MDPI, Basel, Switzerland This article is an open access article distributed under the terms and conditions of the Creative Commons Attribution (CC BY) license (https:// creativecommons.org/licenses/by/ $4.0 /)$
Department of Malay Studies, National University of Singapore, Singapore 119260, Singapore; mlsmm@nus.edu.sg

\begin{abstract}
This article interprets the narratives of sex manuals produced within the Malay-Indonesian archipelago before the coming of Western colonialism and the dawn of postcolonial Islamic resurgence. In the collection of Malaysian libraries and museums, these manuscripts are largely classified as Kitab Jimak and Kitab Tib. They are all written in the Malay language with indigenous references, though the contents are likely derived from a common genre of texts transmitted from an early Arab-Islamic world and circulated within the region before the coming of European colonialism. The corpora of sexual knowledge in these texts emphasises the valorisation of sexual pleasure in conjugal relationships. Through an extensive list of prescriptions-from sexual techniques to diet, food taboos, medicine, pharmacopoeia, mantras, charms, and astrological knowledge-a near-sacral sexual experience is aspired. Couples are guided in their attainment of pleasure (nikmat) through the adherence of Islamic ethics (akhlak), rules (hukum), and etiquette (tertib). The fulfilment of women's desire in the process is central in these observances. Nevertheless, despite placing much emphasis on mutual pleasure, these texts also contain ambiguous and paradoxical pronouncements on the position of women, wavering from veneration to misogyny. The article also highlights how intertextual studies of similar texts throughout the Islamic world can be a new focus of studies on the early history of gender and sexuality in Islam.
\end{abstract}

Keywords: Islam; sexual ethics; pleasure; spirituality; sexuality

\section{Introduction}

Within Islam, it appears innately natural to locate the body as an intimate space of profound meaning. The corporeal significance is given many different inflections; as an object of cleansing in the inscription of religious purity (Khuri 2001), as the habitation in which health and wellness may reside through the medicine of faith (Rahman 1987), as a location for the ethics of gender dominance or resistance (Ali 2016), and simply, and most directly, as the site of sex and sexuality (Bouhdiba 2012; Myrne 2020). Given the centrality of the body in Islam, this article adds to the field of scholarship on corporeality. The body as instrument and passage of sexual pleasure is articulated through a gendered dimension.

The sex manuals studied in this article are handwritten texts, referred to as Malay manuscripts, produced before the advent of printing technology. They are all written in the Malay language with indigenous references, though the contents may have been derived from similar genres of texts transmitted from an early Arab-Islamic world, circulated, then translated and even re-written within the region before the consolidation of European rule. I analyse the meanings of women's place in the sexualised space and imagination of indigenous writers of these texts who may be the copyists, authors, translators, or transmitters of Islamic knowledge. Similar to the Greek examples given by Foucault, women were not "active actors" in the "drama of pleasures" (Foucault 1990, p. 47). However, in the manuals of the manuscripts collection, they are central in the observance of ethics (akhlak), rules (hukum), and etiquette (tertib) in the fulfilment of sexual pleasure.

This study owes its clarity and insights to the work of Pernilla Myrne (2018a, 2018b, 2019, 2020) on gender and sexuality in early medieval Arabic literature. Her studies fill 
much of the gap in locating the historical and cultural source of Malay sex manuals in the collection of manuscripts kept in Malaysia. Although Malay sex manuals are not direct translations of some of the important Arabic works studied by Myrne, such as the Encyclopaedia of Pleasure, or the Pleasure Park for Friends on Intimate Relations with Their Beloveds, or writings by al-Suyuti on sex and marriage (Myrne 2018b), they resemble shades of meanings and intentions espoused by these Arabic sources produced between the 10th to the 12th centuries. The intertextual dimension of these manuals opens up possibilities for a longue durée study of gender and sexuality in a transregional and transcultural Islamic history.

The first section of this article explains the sources and methods used for the study; the next section discusses literature on the prevalence of sex and erotic literature in Islamic history; and the third and main section of the article analyses the corpora of sexual knowledges contained within these manuals, namely the innumerable instructions on intimacy and lovemaking. The approach I use in deconstructing the manuscripts is to locate gender positionings and expectations within the narratives and show how these are related to the methodical means of valorising sexual pleasure. This third section is followed by a discussion of the ironies in the portrayals of women in the manuals given that other accounts have evidenced a more gender egalitarian aspect of Muslim Southeast Asia. The article highlights that Malay sex manuals formed part of an important textual resource in the transmission and circulation of Islamic knowledge; sexual pleasure in conjugal relations as one of the teachings, with gender relations being one of the more contested facets of this process.

\section{Materials and Method}

This article engages a method of close reading to interpret data for the study. The primary data is drawn from Malay pre-20th century manuscripts and those classified as falling within the genre of manuals or handbooks on sexual knowledge. These are instructions on the topics of the 'art', or 'science' of coition and lovemaking. The handwritten feature of Malay manuscripts meant that most were produced before the 17th century and the coming of printing technology into the Malay archipelagic region (Gallop Teh 1990, p. 92). They, thus, form an important corpus of pre-imperial, pre-colonial, and pre-national repository of local knowledge production and representation. Though these materials preponderate in libraries, museums, and archives globally, outside the field of philology these manuscripts remain under-studied and insufficiently problematised, especially through a gender and sexuality framework.

Why the method of close reading? Close reading employs an interpretive mode to the study of texts, which was originally and predominantly employed in the study of literary texts (Bode 2017). However, its potential for use in all forms of written, and even visual representation, is increasingly being relied on to produce a richer and nuanced understanding behind the meanings of these materials (Bares et al. 2020). Close reading is a "technically informed, fine grain analysis" of textual materials and can be used to answer bigger questions (Smith 2016, p. 58). In this study, the manuals can lead us to dwell on a larger research problem, namely, the position of women in a certain time of history. I use close reading as a method to interpret texts critically, to read against-the-grain and move it "from the margins of the field to the center" (Smith 2016, p. 62). Close attention can be given to "what a text is saying" and "how it's being said" (Bares et al. 2020, p. 31). The method of close reading does not aspire to a positivist claim on the materials studied. It relies on the "humanities' interpretive lens" rather than solely on "the positivism of the sciences" in historicising societal conditions (Bares et al. 2020, p. 30).

Manuscripts that I have generically referred to as sex manuals speak to the importance of intimate relations within a Malay-Islamic cosmological and spiritual rulebook. This is not to say that there is an essentialist 'Malayness' or a monolithic Islam that characterises the meanings behind the texts. Rather, they tell a story of the transmission, circulation, and assumption of a faith around the corporeal site. The contexts and contents of these texts can 
also be read in various ways; as inspiration and continuation of an Arab-Islamic medieval tradition of writings on sex and erotology; as influenced by an Indic-Buddhist tantric tradition complimenting an Islamic-sufistic approach; or as a uniquely indigenous representation and modulation of sexual knowledge circulated through the fluid movements of traders, mystics, saints, and religious scholars of the times.

\section{Early Sex Literature in the Islamic World}

At its most superficial level, sexual licentiousness is associated with the West, sexual prudishness with the East. Nothing can be further from the truth. The meaning and abstraction of sex is not the monopoly of the West but has long resided within pre-modern and non-Western texts and writing traditions. Bouhdiba's study on Sexuality in Islam (Bouhdiba 2012), Ghandour's Lust and Grace: Sex and Eroticism in the Works of Muslim Scholars (Ghandour 2017) and Myrne's extensive and in-depth analysis of the 10th century, Encyclopaedia of Pleasure (Myrne 2020), comprehensively document the array of Arabic literature on sex, lust, and eroticism, with a large collection not confined to matrimonial or heterosexual unions. Erotic guidebooks called Nuzhat and books on coitus called Kutub alnikah or Kutub al-bah were already in production by the 9th century in Abbasid Baghdad (Dangler 2015, p. 16). Ghandour (2017) lists at least 24 titles on the subject of sex and eroticism in book catalogues of prominent 10th century Arab and 17th century Turkish religious scholars. Attesting to the breadth of scrutiny and richness of the subject, this set of literature has also been sub-classified as either belonging to manuals on the teaching of marital ethics, the teaching of sex, or the teaching of eroticism (p. 29).

Early Arabo-Persian Muslim texts were the richest in terms of content and styles. They not only provided the groundwork of present religious moral and jurisprudential principles, but also contained other genres of writings that by today's standards may be considered salacious and lewd. Bãh literature was both pornographic and medical in form (Franke 2012). The former contained references to all forms of sexual pleasure, from masturbation to 'deviant' sexual acts, some written with humour. In both, there were chapters on lesbianism, pederasty, and pimping, showing the somewhat thin line between erotology, sexual medicine, and pornography.

Within its medical rubric, sexual pleasure was emphasised as a curative goal towards health, happiness, and wellbeing (Myrne 2020, pp. 13-44). For both males and females, sexual intercourse sans its reproductive outcome was the main concern to the extent that one chapter in the 13th century work by Al-Tusi was entirely devoted to the prevention of pregnancy (Franke 2012, p. 167). The focus on love has been one of the predominant characteristics of Sufism in Islam (Azdajic 2016, p. 100). As well, "languishing" from the intensity of loving has also been a feature of Middle Eastern literature (Khorangy et al. 2018). Sex was not even linked to matrimony, but rather to desire (Dangler 2015, p. 14). Sex, not marriage, was the preoccupation of authors, poets, and scribes in the Islamic past.

When Europeans first discovered this literature around the 18th century, they translated, and in many cases abridged, redacted, and expurgated these works to suit the moral sensibilities of the European market. Examples of popularly consumed literature that are still easily available today include up to at least four volumes of The Thousand Nights and One Night (Mathers 1972), and the 15th century, The Perfumed Garden of Sensual Delight (Muhammad Al-Nafzawi 1999). It was not something that European moral convention, at least of the pre-20th century, found easy to accept, for The Thousand Nights and One Night was a "sexological encyclopaedia before its time", containing all forms of sexual experiences one can think of-" "prostitution, polygamy, homosexuality, male and female, impotence, frigidity, voyeurism, narcissism" (Bouhdiba 2012, p. 137). The "sexual world" of The Thousand Nights and One Night also constitutes "one of the quintessential examples of world literature", and a "treasure for studies of sexuality and gender" (Ghanim 2018, pp. 1-7). Sex as a trope was a ubiquitous feature in the literature of the early Muslim world, be it erotic, bawdy, vulgar, salacious, humorous, outrageous, poetic, transcendental, or instructional in form. 
Although not as rich and bewildering as the repertoire of works from the Arab, Persian, and Turkish world of the past, the manuscripts produced before the coming of Western colonialism in the Malay world were also devoted to an assiduous and unrestrained attention to the subject of desire, eroticism, and coition. Early Malay-Islamic sex manuals contained little clues on how sexual desire or behaviour would have been regulated, as they were almost wholly focused on heightening pleasures, and how to address limitations, disease, and ailments, which could impede such a goal. In this way, the prescriptions were in line with the tone of many Islamic erotic literature, in which sex was not seen as something to be restrained. The Prophet engaged in sex "frequently and with delight" according to 14th century theologian, Ibn Qayyim al-Jawziyya, author of Medicine of the Prophet (Al-Jawziyya 1998, p. 182). Malay sex manuals can, thus, be historically and culturally contextualised as either a continuation, variant, improvisation, or localised modification of these literary and theological traditions.

\section{Manuscripts of Malay Sex Manuals}

\subsection{Background}

In the collection of the National Library of Malaysia, there are at least 100 volumes of manuscripts touching on sex and eroticism. Specifically, these are knowledge compendia on the techniques, ethics, rules, and etiquette of lovemaking that conform with the Prophetic tradition in Islam. Some of these manuscripts are also part of a larger subject text on medicine, as sexual activity was considered a source of wellness, and disease in cases of its dysfunctionality. Sections on sex and marital relations are found in epic manuscripts on kingship traditions and rules such as the seven-volume Bustan al-Salatin. Sexual references have been penned in syair and sajak (local poetical verses). The provenance and authorship of these texts are largely unknown, and they are archived variously in the form of volumes, treatises, notes, or even scraps of writings on paper. Many of the volumes are without any specific titles, the contents of which are reproduced in assorted texts or recur elsewhere in different or modified versions. In the Malaysian collection, ${ }^{1}$ a listing of these sex manuals has been generically catalogued as Kitab Jimak (Book on Coition), Kitab Tib (Book on Islamic Medicine), or Ilmu an-Nisa (The Science of Women). Manuscripts under the category of Petua dan Azimat (Sacred Tips and Charms) and Petua Rasi (Effectual Sacred Tips) may also contain knowledge on sex.

Only a few scholars, primarily literary philologists, have studied this specific group of Malay manuscripts. Amongst them, Vladimir Braginsky has been the most prolific with three publications on the sex-related manuscripts (2004, 2017, and 2019). Harun Mat Piah was a pioneer in uncovering Malay erotological manuscripts, his first publication on this subject being a paper issued by the National Library of Malaysia (Harun 2014). Harun's work, Seksologi: Ilmu Perkasihan Melayu (Sexology: Malay Knowledge on Love) was posthumously published in 2019 with co-author Naseer Sobree (Harun and Naseer 2019). ${ }^{2}$ The works of Braginsky and Harun and Naseer contain transliterations or Romanised version of Malay language texts written in the Arabo-Persian script, or known as Jawi writings in Malay. There are also translations of some parts of these texts into English (see Braginsky 2004, 2017, 2019). I have relied on these sources for the manuscripts used in this article. ${ }^{3}$ I add another dimension to the studies by Braginsky and Harun and Naseer by reading the same texts through a gender lens.

Braginsky's studies of eroticism in Malay manuscripts tend to treat them as deriving from a genre of "traditional religio-mystical literature" (Braginsky 2017, p. 251). Among the manuscripts he studied were those originating from Aceh and Java including the Bustan as-Salikin, a ten-chapter treatise that contains the section 'Ilm an-Nisa ${ }^{4}$ (The Science of Women). The latter is most lucid and rich with knowledge on sex. Other important works studied by Braginsky in this genre are poems of unknown authorship, namely the Syair Bahr an-Nisa (Poem of the Sea of Women) and the Sajak Perkataan Alif (Poem of the Alphabet Alif). 
Braginsky's purpose was to establish that sexual acts and techniques described in these Malay texts were a result of the influence of Sufism, tantrism, and sexo-yogism (Braginsky 2004, 2017). While acknowledging that Malay texts on coition (jimak) had a distinctive indigenous slant to them, he postulated that the absorption of Indic-Hindu and Buddhist traditions, which preceded the coming of Islam into the region, had been most influential in these manuals. In tantrism, an orgasmic sexual union is equated to the achievement of a high state of spirituality (Skora 2007; Lousada and Angel 2011), while these sex rites are also said to have elevated women's identity (Shaw 1994; Biernacki 2006). Braginsky, thus adduced that the spiritual elements of sex as elucidated in Malay texts have similarities with Hindu-Buddhist tantrism and sexo-yoga practices.

To trace Malay erotology texts as solely influenced from the above source is to limit their wider transregional and transcultural influence. What is scribed in them is meant to be in alignment with Qur'anic verses and Prophetic traditions (hadith) even if elements of tantrism are present. In surveying these manuscripts (written in Malay and professing to be Islamic), this article does not posit that there is a Malay or an Islamic essentialism that is being highlighted through the texts. Both local particularisms as well as transregional characteristics of Islam in the early period of its spread beyond the Arab world are inscribed in the contents of these texts. A common trope running through them is the invocation of Qur'anic verses and hadith as a stamp of their Islamic quintessence and authenticity. As Braginsky (2017) himself notes:

Repeatedly quoting the Qur'an and hadith, the prose Ilm al-nisa strives to confirm the usefulness and pleasure of coition and the fact that Allah approves of intimate relations between men and women and absolves the sins of lovers. (p. 262)

Malay sex manuals have a near-equal status to that of religious texts, by their stress on knowledge, wisdom, and know-how on sexual intercourse as being in accordance with the Prophet's tradition. The manuals are almost always prefaced as being rules for coition (hukum jimak) for men approaching women with whom they are in permissible marriage (halal nikah). Proper coition is considered sacred and in need of a corporeal site heavily invested in material and spiritual complement to arrive at a state of pleasure. Harun and Naseer (2019, p. 19) inventorise an extensive array of prescriptions and rulebook themes that these manuals contain:

1. Method, decorum, position, level, and timing of coition in accordance with the manner of the Prophet

2. Levels of sexual permissibility that are wajib, sunat, harus, makruh, and haram ${ }^{5}$

3. Method for strengthening the overall capacity for coition

4. Method for strengthening all sexual organs for the perfection of coition

5. Aphrodisiac for arousing sexual desire

6. Medicine and cornucopia for treating sex ailments and the lack of sexual desire for both males and females

7. Diet, nutrition, food taboos, and other prohibitions for sexual wellbeing

8. Supplications, mantra, charms, spells, and amulets for attracting love interests or repulsing unwanted suitors

9. Skills in the art and techniques of seduction

10. Astrological knowledge and fortune-telling to affect favourable choice of mates and auspicious sexual experience

All throughout, sprinklings of Qur'anic verses, sayings, and manners attributed to the Prophet (hadith), invocations of names associated with the Prophet's family, and various other Islamic symbolisms lyricise the textual content of these manuscripts. The fact that these had been scribed as prescriptions purports a didactic element to them, in which knowledge of intimacy was meant to be transmitted, circulated, and most possibly practised as the texts would have them. 


\subsection{The Valorisation of Pleasure}

The important, even unambiguous purpose of knowledge within these manuals is the attainment of an entitled if not perfect sexual pleasure (nikmat). This must be guided by Islamic ethics (akhlak), rules (hukum), and etiquette (tertib). What constitutes these 'ethics', 'rules', and 'etiquette' is a set of very precise guidelines and prescriptions for coition (jimak). Pleasure can only be valorised if rules (rukun) and etiquette (tertib) are observed; its benefits not necessarily the logical outcome of sex leading to reproduction but of the sparkling of love and amorousness between the partners (berkasih-kasihan). Several themes highlight how sexual pleasure is valorised for both males and females. ${ }^{6}$

In the sections below, I discuss how the contents of the manuscripts have instructed that (i) foreplay is to be choreographed before actual intercourse; (ii) the vulva and clitoris are to be regarded as the threshold of pleasure; (iii) climax or orgasm is to be simultaneously achieved; (iv) mantras and supplications are to be recited to sacralise, as much as to intensify the sexual experience; and (v) pharmacopoeia and abortifacient are to be essential in the sustainment of a desirous and desiring body.

The frequent invocation of the prophet Yusuf (who is eulogised as strikingly handsome) and the passionately smitten Zulaikha in passages of the manuals shows that romantic love is not lost in their faith-driven prescriptions. Qur'anic verses (in Chapter 12 , surah Yusuf) do not mention the name of Zulaikha, but only in reference to her as "the wife of Aziz". ${ }^{7}$ It is only through interpretations by commentators of the Qur'an that the name Zulaikha is used, with the telling and re-telling of her love tales with Yusuf in many different versions (Merguerian and Najmabadi 1997). There are many alternative stories, particularly from the Shi'a traditions, which also narrate that they eventually married ( Bouhdiba 2012, pp. 19-29). In the Malay manuscripts, their union is often referred to as the paragon of passion and pleasure, which may also have been inspired by the 15th century Persian poem by 'Abd al-Rahman Jami on the allegorical romance between Yusuf and Zulaikha (Yaghoobi 2016).

\subsubsection{Choreography of Foreplay}

According to the manuals, one of the first etiquettes to be followed is the performance of ablutions (wuduk) at the onset of intercourse. This is sunat (obligatory though otherwise not a sin) for the couple. More decorum follows with supplication $\left(d o a^{\prime}\right)$ seeking God's protection. The version below seems to be an expression of a form of male anxiety in his fear of the 'devil' interfering in the process.

If we desire this [i.e., to gain the female fluid], we must first destroy her [the woman's] 'cupola' (kubat). We should greet her on her right, [saying]: "Peace be upon you, O spirit of Allah, Allah is the light delightful (nûr al-ladhdhi) within the light refined (nûr al-latîf)". Then [we should] greet her on her left, saying: "Peace be upon you, O [an illegible word] Prophet Muhammad, Messenger of God". After that we should recite [the supplication]: "I take refuge with Allah from the damned Satan". ("Ilm al-nisa as translated in Braginsky 2019, p. 392)

A more matter-of-fact version of these supplications involves asking for God's protection against evil (Satan) so that no misfortune will befall upon the sexual experience and procreation (Kitab Jimak MSS 686).

Several techniques are then prescribed as the prelude to intercourse itself. These can be methodical and elaborate. In a manuscript catalogued as Bustan al-Salatin (Bab 7 MSS 3059) in the collection of the National Library of Malaysia, about 16 pages are devoted to detailing techniques of foreplay based on the hadith and advice from the Ihya Ulumuddin written by the 12th century jurist of Baghdad, Imam Al-Ghazali (see Al-Ghazali 2012). Other manuscripts catalogued as Kitab Jimak/Kitab Tib MSS 2905 and Kitab Jimak MSS 495 contain step-by-step techniques for a man to initiate acceptable and pleasurable intercourse.

Though the prose may vary between the texts, the purpose of these manuals is similar, which is to instruct on the sacrality of the conjugal union in their detailing of a multistep 
ritualistic process of foreplay. This is intended to encourage the man and his partner to be in a state of banter and playfulness (bergurau-gurau dan bermain-main) in this first stage, as it is noted that this was what the Prophet did with his wives. A relatively brief instruction on foreplay can also be found in Kitab Jimak MSS 495.

There are also more elaborate choreographed guides to foreplay. The most detailed of these involves what is termed the 12-step kiss, equated to a journey through the 12 makam or 12 stations of pleasure. The detailed instructions for this process involve supplications in Arabic for each step of the kiss (Kitab Jimak/Kitab Tib MSS 2905). There is another version, which dispenses with the Arabic supplications for each of the 12-steps, and instead, employs a prose that is more graphic in instruction, explicit in its sense of sensuality, and takes the reader through a complete sequence of lovemaking from foreplay till the attainment of female orgasm. The journey towards climactic orgasm, which begins with foreplay and ends with a woman's submission to her partner, is equated to the state of passion memorialised between Prophet Yusuf and his beloved, Zulaikha.

Do not loosen the grip so as to reach the ultimate station for the woman to lose herself to the world till she comes to face with the Gracious One and viewing all that is wondrous, or what is called paradise on earth. And when the woman is awakened from her reverie, she will prostrate at your feet. Whomever would have achieved such a command would be likened to Yusuf and Zulaikha. (Kitab Jimak MSS 119)

All of the above allusions and prescriptions for foreplay can be found in variant forms in other prose such as the 'ilm an-nisa (The Science of Women) within the Bustan al-Salikin of Acehnese origin (Braginsky 2017, p. 254). This version is more heavily laden with references to Prophet Muhammad as compared to the versions cited earlier. The techniques of foreplay cover four stages through which the Prophet is said to have approached women, namely, the gaze, the breath, the touch, and then coition. The 'ingredients' of obligatory foreplay included "prelude", "steady gazing", "practices of breathing and touching", "coition and stations", and knowledge of "stations with doors and techniques of their opening", or "stations of bliss" (Braginsky 2017, p. 250). Metaphorical phrases such as the "sea", "voyages", "fluids", "hub", "cupola", "base of flower" are also used to evoke the journey of lovemaking (Braginsky 2019, pp. 392-93).

All these texts are directed to the male reader, even though the listening audience may include both sexes. The active actor in the choreography of pleasure is male, to the extent that there appears to be an undue 'burden' on his part to be singly responsible for the achievement of bliss and ecstasy for both. However, while men appear to be the more dominant initiators of sexual acts, achieving high states of ecstasy is predicated on a duality and mutuality of pleasures.

\subsubsection{Vulva and Clitoris as the Threshold of Pleasure}

How can a woman's worth and superiority be assessed from these manuals? One way would be to decipher the meanings of an allegorical poem, the Syair Bahr an-Nisa (Poem of the Sea of Women). The voyage of sea-crossing in this poem symbolises the circumstance of a male organ (the boat) penetrating the vagina (the sea), and its caresses around the vulva (metaphorically referred to as stations, doors, and estuaries). It is one of the most exquisite odes to lovemaking, though its authorship and provenance are unknown. The poem appears to have been written in several versions and is believed to be an adaptation of an Arabic poem. An Acehnese version in the British Library contains this Arabic proverb: "A man who finds no pleasure in women, will find no pleasure in the world to come" (Liaw 2013, pp. 481-82). The Malay version is likely to be a recomposed version of this Arabic poem, with a more distinct or subtle localised metaphorical inflection to wax lyrical on the wonderment of a conjugal union.

Braginsky's translation of one of the versions comes from the Leiden collection (Braginsky 2004). Another at the National Library of Malaysia forms part of a manuscript, the Syair Laksana Kita (MSS 2590) and is reproduced in Harun and Naseer (2019, pp. 179_ 
86). The Leiden version alludes to the importance of pleasing women through skilful lovemaking. The poem is phrased with makam or "stations", or vital spots and erogenous zones around the vulva. The phrase tawaf in the Leiden version is meant to denote circumambulation of the penis around the vulva for the woman's arousal. Two of the stanzas from Braginsky's translation (Braginsky 2004, p. 151) repeatedly denote that a man should aspire to be adept at lovemaking.

[stanza 24]

That 'station' which is boundless

Is allotted to the wise men skilled in lovemaking

If you have that skill, $\mathrm{O}$ friend

[You] will experience ecstatic bliss

[stanza 30]

If you acquire those qualities, $\mathrm{O}$ friend

Your beauty, in the eyes of women, will become peerless

They will reach self-oblivion when enjoying intimacy

With the wise man skilful in lovemaking

Another Malay version of Bahr an-Nisa is found in the manuscript, Syair Laksana Kita ((A Poetry Resembling Us) (MSS 2590)) and contains 63 four-line stanzas. This rendition appears to be a more subtle version of the Leiden manuscript used by Braginsky. The metaphors and allusions used here are more localised and suited to the maritime nature of the Malay world. For example, there are no Arabic phrases such as makam, tawaf, or references to the vulva and clitoris as "the shell of a pearl oyster" (Braginsky 2004, p. 151). However, the names of the Prophet's wives, Khatijah, Maimunah, Salamah, and Aisyah, and his daughter Fatimah and son-in-law Ali, are retained. These names are associated with zones around the vulva.

In the verses, Khatijah is metaphorically positioned at the top, Maimunah on the left, Salamah on the right, and Aisyah at the bottom of the vulva. The highest pleasure point is described as being located at the kuala or estuary of the river. This appears to be a direct reference to the clitoris. Orgasmic bliss is described with words and phrases such as nikmat (pleasure), gementar sendi dan tulang (trembling bones and joints), letih (exhausted), lesu (drained), lazatnya (so delicious), syurga terbuka ketujuh pintu (seven doors of heaven opened), or pintu hidayat dibukakan Tuhan (door of guidance is opened by God). The centrality of the female, specifically the vulva, as a mount in the sea of bliss is captured in the following selected stanzas of the Syair Bahr an-Nisa.

[stanza 11]

The sea of women is all ready

For the conquest of seven territories

Seven layers of the fort will I traverse

The weapon is ready and waiting

[stanza 18]

This is the perfect way

The incursion of Ali Murtada

Into Siti Fatimah al-Zahra

A compendium of complete bliss

[stanza 21]

The estuary above is named Khatijah

That which is bliss of perfection

Said the wise and just

But Awang will still plan

[stanza 43]

Awakened from the daze

Drained and exhausted all over 
The pleasure is immeasurable

Bones and joints crumpled

[stanza 53]

The sea is startled the waves silenced

Bones and joints all shaken

Her colour as if lost to the world

Withered pale but her face is aglow

Another poem of Acehnese origin, the Sajak Perkataan Alif (Poem on the Alphabet Alif) also gives attention to the vulva and its erogenous zones. Each 'station' around the vulva exudes different kinds of bliss; from the "bliss of passion" (ni'mat isyki) at the station of Siti Maimunah, to "bliss of this world" (ni'mat dunia) where the Siti Khadijah station is located. A station that exudes "bliss of the world to come" (ni'mat akhirat) is the Siti Salamah station, while "the Divine bliss" (ni'mat Allah) is the station of Siti Aisyah. The highest station belongs to Fatimah, located at the pusat belanak (source of the mullet fish), where there is "bliss of [complete] self-abnegation" (ni'mat nafi) (Braginsky 2004, pp. 166-67).

In various passages of another Malay manuscript, the clitoris is variously euphemised as the "estuary" and "the highest station" or even as "the source from where the mullet fish comes" (pusat belanak). Other metaphors used in Malay manuals include the terms payung Ali (the canopy of Ali) to describe the hood of the vulva in Kitab Jimak/Kitab Tib MSS 2905, and biji keladi (caladium seed), in its resemblance to the vagina, in Kitab Jimak MSS 686.

In Kitab Jimak MSS 686, there is also a stylised illustration of the vulva, drawn in an oval shape like a heart or diamond. Around this ornately stylised 'vulva' are descriptions of lovemaking positions. Notations of the different stations representing the Prophet's wives and daughter are also scribed around the vulva-shaped diagram.

The invocation of Ali and Fatimah harks back to an earlier influence of Sufism and Shiism in the practice of Islam within the Malay world and in many Malay manuscripts produced around the 17th century (see Jelani 2005 on sufism as a central feature of Islamic faith then). These references to important personages in Shi'a Islam are visibly absent in Malaysian Islamic mainstream literature today. ${ }^{8}$

\subsubsection{Synchronisation and Simultaneity of Orgasm}

The valorisation of pleasure must include the man's obligation to ensure that the woman must first be in a high state of arousal before reaching climax (inzâl in Arabic) in sexual intercourse. A man is not encouraged to ejaculate before a woman reaches orgasm. Without this observance, there will be no mutual pleasure and affection:

[The] result of simultaneous orgasm and the meeting of male and female fluids is best as that will be more pleasurable for both, and will stimulate love for one another. (Kitab Jimak MSS 686)

One manual prescribes that a man must delay his ejaculation and wait for the woman to reach her highest peak of arousal before the simultaneous orgasm:

And if the ejaculation of the husband is to come earlier, it is best that he waits for the wife to climax first so that they may come together. (Kitab Jimak MSS 686)

According to one of the passages in a manual, so beneficial is good intercourse, which ends with a simultaneous climax, that a clever and industrious child will be the outcome of such a bond:

[...] the union of semen and fluids which will heighten love and pleasure for both and a child borne out of this union will inherit the traits of cleverness and industriousness. (Kitab Jimak MSS 495)

\subsubsection{Mantras and Supplications}

Added to the prescription for foreplay and simultaneous orgasm is the accompaniment of mantras and supplications, that are considered part of the sacral ensemble of lovemaking 
and the acquisition of pleasure. The complement of "Prophet's wives" is used in recitations such as this.

Oh Salamah, Maimunah, Khatijah, Aisyah

Clear yourself of Fatimah's door

I wish to insert a lance

To greet a stalk of flower

In the Prophet's cage

I wish to arrive at the paradise of Jannatun-Naim

With the grace of Prophet Muhammad (Kitab Jimak/Kitab Tib MSS 2905)

Another mantra is recited to enhance male sexual prowess and seminal production.

I consume my prophet's semen

I fertilise my body

Blessed is my prophet's semen, in the service of Ali

Replacing my own fluid, gushing out in full

Replenished as before

Long shall my penis remain firm

Just like that of the exalted Ali (Kitab Tib MSS 1292)

Yet another is for maintaining the sexual allure of the man, with the invocation of the prophet Yusuf:

When there be 1000 people walking by

It is only me that their gazes will fall upon

My looks are as good as Yusuf (the prophet)

Even a flying bird will be stopped in its flight

Even rushing waters will halt, as if to fortify my voice

Seeing my looks, as if it is that of Yusuf's

Sweet as you sit, sweet as you stand

Sweet is the laughter, sweet is the smile,

just as that of Yusuf's

Hey I am Yusuf, the prophet

Bow and prostrate all of Muhammad's ummah

I submit with this gift of supplication I have with me (Kitab Jimak MSS 119)

Many of the guidebooks contain innumerable mantras used by men for the enticement of women, more than those prescribed for women to seduce men. Thus far, only one manual has been known to be authored by a woman, Perhimpunan Gunawan bagi Laki-Laki dan Perempuan (A Compendium of Charms for Men and Women). The author, Khatijah Terung, lived in late 19th to early 20th century Riau (in current Indonesia). Included in her book are various spells and incantations composed by, and for the use of women (Ding 2002; Musa 2021).

\subsubsection{Pharmacopoeia and Abortifacient in the Sustenance of the Desiring Body}

The rules of lovemaking not only revolve around intercourse but extend into the care of the body. Preceding even foreplay is the subjectivity of being desirable as well as desirous of sex. For these, there are numerous concoctions to be consumed orally, and rubbed or slathered over the body for the purposes of enhancing sexual pleasure. All the botanical ingredients mentioned in the manuals are locally available. For example, ground basil leaves are prescribed for insertion into the vagina before the commencement of intercourse, after which,

[...] The husband will be in bliss, the wife will be in bliss; the more revitalized the gift of pleasure and the fulfilment of love between the couple just as Laila and Majnun, and Zulaikha and Yusuf. (Kitab Tib MSS 300)

Pleasure is also augmented with a tightened vagina through another prescription of a ground mixture of vinegar, lime chalk, pepper, red onions, and Javanese caraway 
seeds inserted into the vagina (MSS 1219 in Harun and Naseer 2019, p. 129). Finally, since childbirth may get in the way of pleasurable intercourse, the manuals contain numerous concoctions for aborting the foetus, such as the following,

[...] the root of the remunggai and the leaf of benalu api, so grind this into a paste, drink for three days or seven nights, for sure, the foetus will be aborted. Insya Allah. (Kitab Jimak MSS 119)

The above prescriptions for enhancing pleasure resemble that of their Arabic predecessors. The above formulae, recipes, and methods could be simply picked up from books on sexual pharmacology of the medieval Arab world (Myrne 2020, pp. 34-39). Nevertheless, they have been suitably adjusted to allow for the use of local herbs, plants, and ingredients in their concoctions.

\section{But Women Remain the Chattels, though the Situation Is Ironic}

It would be misleading to interpret the female-centredness of these manuals to mean that women were treated as equals. Some of the texts could have been translations from other sources outside the region and contain misogynistic dictates. For example, in the Kitab Jimak (MSS 686), which is scribed as a translation from the Arabic by one Ahmad bin Sulaiman between the 17th to 19th centuries, there are many references to hadith that are unfavourable towards women. This manuscript is 86 pages long and contains many of the passages on lovemaking discussed before. While the Prophet's tradition of respecting consensual and desirous rights of women is emphasised as part of Islam's sexual ethics, there are contradictory dictates about a woman's place in marriage.

For instance, the passage below is a hadith commanding women to never refuse sex whenever their husbands demand it, even if this means doing it on the camel's back.

And thus pronounces the Prophet, "As the husband has the right over his wife, do not refuse him [for sex] even if he wants it upon the camel's back, this is to be fulfilled". (Kitab Jimak MSS 686)

Likewise, the wife's refusal to go to bed with her husband will invite his wrath whereupon the angels will be summoned to torment her.

And pronounces the Prophet, "if a wife is called upon by the husband to his bed and if she refuses, angry would the husband be towards the wife to which he will summon all the demons upon her till dawn". (Kitab Jimak MSS 686)

Women were considered to have uncontrollable lust. To restrain this, a certain pulverised concoction of limes, red onions, peppercorns, and ginger, among many others, are recommended for their consumption, so that, "by the Grace of Allah this will diminish her desire (nafsu)" (Kitab Jimak MSS 1292).

Women's infertility was 'diagnosed' as stemming from their own deficiency. In one of the treatises, Kitab Tib MSS 1292, copied by a Terengganu native, Haji Mahmud al-Jawi in Patani in 1819, seven ludicrous causes are listed to be behind this condition, none of which is attributed to the man.

First, her womb is misplaced, hence impossible for the sperm to enter. Second her womb is full of wind, hence the sperm cannot remain there indefinitely. Third, there is too much flesh in her womb, hence difficult for the sperm to be lodged within. Fourth there are worms in her womb, devouring the sperm as it reaches there. Fifth it is because the womb is too hot, hence the sperm will be boiled and burnt by this. Sixth it is because the womb is too cold, and the sperm will be dislodged and thrown out of it. Seven it is due to the devil blocking the sperm from entering the womb. Hence it is necessary to treat all seven of these causes so that by the grace of Allah a child will be gifted. Only God knows best. (Kitab Tib MSS 1292)

Women are heavily objectified in the texts, which classify them according to the characteristics of at least 10 animals, including the pig, horse, dog, lion, rat, and the goat (Kitab Tib MSS 686). This version of the Kitab Tib also mentions a hadith in which the 
Prophet was said to have indicated that there are five types of women whom men should not wed.

[...] first a woman who is so obese, second a woman who is too thin and lanky, third a woman who is old and menopausal, fourth a woman who is short and hideous and fifth a woman who has a child who is not your own. (Kitab Jimak MS 686)

Such an attribution of the above to a hadith is likely to be dubious as the Prophet himself had among his many wives, those who were reported to be old (Khatijah), portly and unattractive (Saudah), and also widowed (Hafsah, Ummi Salamah). Such misogynistic passages in the manuals can perhaps be read as an importation of other cultures-as many of the manuscripts were thought to be translated from Arabic —or that only selective, even unreliable hadith, had been used to justify a creeping patriarchal orientation among some of the transmitters and proselytisers who wrote the manuals.

The misogynistic treatment of women can be found in various other manuscripts serving as the guide for proper behaviour among married couples. The Hikayat Fartana Islam and the Kitab Muhimmah are two such works whose main dictate is women's unquestioning obedience to their husbands (Hijjas 2013, pp. 219-28).

On the other hand, women within the Malay world court circles were also known to be composers of poetry (syair) with themes of strong female protagonists (Hijjas 2011). As mentioned earlier, Khatijah Terung, a woman from Riau, wrote her own sex manual for the use of women (Ding 2002; Musa 2021). In the pages of this manual, female agency is recognised as equally important in the enhancement of sexual pleasure, especially in her ability to gain control over the man. In Khatijah's compendium, the mantra below, if recited, is expected to see a husband become uncontrollably in love with his wife (teringatlah ia kepada kita, hampir tiada dapat diperikan), returning back home even if already away across the seas (Jika di seberang lautan sekalipun, nescaya dan terkadang datang semangatnya melawat kita).

Bare open the heart

Of so and so

Submit your love for me

And be madly intoxicated in your lust for me

Let the child of so and so feel this

It will be delicious, satiating and blissful

Just what my cunt desires

His body and soul surrendering to me

May this supplication be granted

In the name of Prophet Muhammad (Translated from Harun and Harun and

Naseer 2019, p. 137)

Prioritising their consensual and desirous involvement in sex to achieve simultaneous orgasms suggests a certain dignified status of women at the time. On the other hand, pleasing a woman could be interpreted as acquiescing her into obedience, loyalty, and allegiance to her spouse. Even if there was an informal code of conduct or rules of gender differentiation to subjugate a woman during the time of the manuals' circulation, this did not have the force of a Syariah statute. ${ }^{9}$ The ideals of masculinity and femininity in accordance with Islamic dictates may instead have been transmitted through many iterations of early (from the 10th century) Arab sources such as that of al-Suyuti's guidebooks (Myrne 2018b). These ideals were construed as the teachings of Islam with gender characteristics posed to be at opposite ends-masculinity was associated with sexual prowess, while femininity with faithfulness, obedience, and lustfulness (in need of taming) (Myrne 2018b, pp. 56-65).

Between their scribed portrayals and their lived realities, there exists a paradox in the status of women in Muslim Southeast Asia. Historical and anthropological studies from the region and the Malay world emphasise a relatively gender egalitarian order, often attributed to a bilateral kinship structure and an agrarian economy that depended on the substantial contribution of both genders (Karim 1992; Andaya 2006). Strong matrilineal 
societies are also a feature of communities in Sumatra and West Malaysia (Hooker 1972; Hadley 2008). Circumstances that existed in early medieval Arab society, such as sexual slavery founded upon an oppressive and highly patriarchal system (Myrne 2019), were not prevalent or absent in the Malay world. Before the consolidation of European colonial rule, there was also a long line of Muslim female sovereigns between the 16th to the early 19th centuries (Cheah 1993; Khan 2017). By the time Islam came into the Malay-Indonesian world, starting from around the 12th century, transmitted traditions and practices would likely have challenged some of these premises, though at the same time, certain others would have been adapted to suit local particularisms and circumstances. The renditions within the manuals may thus represent one perspective of gender and sexuality, out of many competing ones.

\section{Concluding Notes}

This article has tried to uncover the contents of a corpus of 'hidden' or overlooked texts in the form of sex manuals produced a few centuries before the coming of Western colonialism and later-day Islamic resurgent movements. The prose and purpose of precolonial Malay sex manuals are intended to sacralise intimacy by largely applying the Quran and hadith as guidepost of proper ethics and conduct in lovemaking. Sex is prefaced in most of the manuals as an act of coition between husbands and wives, guided by the dictates of Allah and his Prophet. The manuals are lyrical, allegorical, mystical, and locally attuned in terms of their interpretation of faith and religion. Unbridled lust or preponderance towards sexual force and violence are presumed to be tempered by the observance of ethics, rules, and etiquette around sexual conduct and purpose.

There are, however, contradictions and disjuncture as to how gender relations were prescribed. Despite the best intentions of these manuals to forefront women's sexual needs and entitlements, the basis for gender differentiation was still sexualised around the opposing characteristics of masculinity and femininity. Men are the initiators of sexual acts and expected to carry the 'duty' of performing proper coition. Women are the 'passive' partners waiting to be pleased and whose desires and entitlement to heights of sexual pleasure are incumbent upon the skills of men in the realm of lovemaking. While intimacy as prescribed in these manuals conferred some form of equal rights for women to attain mutual and simultaneous sexual pleasure, this did not necessarily translate into other societal attitudes towards women. A male-dominant system, espousing misogyny and the objectification of women, were also recurrently scribed throughout the texts. There was thus a paradox about women's actual status at the time the manuals were written and circulated, given that systems of kinship bilaterality, matrilineal inheritance, and female rulership were also emplaced in Muslim Southeast Asia.

However, in themselves, the sex manuals studied in this article served an important purpose. Through them, readers and listeners of the times were able to engage in a religious conviction through the lens of pleasure. The ethics of pleasure, which place the fulfilment of women's desire as a central precept, were integral to this conception of faith. A further study of these manuals will benefit from using an intertextual approach to trace their transregional and transcultural influences, out of which a longitudinal history of gender and sexuality in Islam can be charted.

Funding: This research was funded by the National University of Singapore HDRSS FY2020/2021 grant. Institutional Review Board Statement: Not applicable.

Informed Consent Statement: Not applicable.

Data Availability Statement: Not applicable.

Conflicts of Interest: The author declares no conflict of interest. 


\section{Notes}

1 The largest collection of Malay manuscripts in Malaysia are kept at the National Library of Malaysia. However, at least 12 other institutions throughout the country also house a substantial collection of manuscripts (Perpustakaan Negara Malaysia 1993). Most in this long list have yet to be studied.

2 Malay authors are cited with their first names, as the second name is not conventionally the surname, but the father's name.

3 Many of the original manuscripts from the National Library of Malaysia used in this article have been transliterated from the jawi script into Roman letters and published in Harun and Naseer (2019). All translations from Malay into English are mine.

4 As this is a transliteration of the Arabic title, it can be spelled variously in the Malay versions as 'Ilm al-Nisa, Ilm an-Nisa, or Ilmu an-Nisa.

5 The classification and nomenclature are based on local Malay practices and understanding of these various degrees of Islamic prohibition and permissibility. An act which is wajib is obligatory and sinful if not performed, sunat means that an action is obligatory but does not count as a sin if not performed, harus is an act that will not bring rewards but is not a sin if not performed, makruh refers to an act that should be abstained, and if done so will bring rewards, while haram is an act that is strictly forbidden.

6 The references within the Malay manuals are overwhelmingly heterosexual. This can be seen as a departure from the early medieval Arabic literature.

7 The story of Yusuf and his female seducer can be found in Chapter 12 (surah Yusuf), verses 23, 33, 50, and 51 of the Quran.

8 Shiism is officially banned by the Malaysian government, whose authority over Islam is represented by the Islamic Development Department (Jabatan Kemajuan Islam Malaysia, JAKIM), and includes the institutions of the Syariah courts and other Islamic bureaucracies (Mohd Faizal and Hui 2017).

9 The spelling of "Syariah" is the Malay convention used in Malaysia, Singapore, and Indonesia. Syariah law was not formalised as a statutory legislation in this region until after the coming of British colonialism.

\section{References}

\section{Primary Sources}

Manuscripts from the National Library of Malaysia and Dewan Bahasa dan Pustaka, Malaysia:

Bustan al-salatin MSS 3059

Kitab Jimak MSS 119

Kitab Jimak MSS 495

Kitab Jimak MSS 686

Kitab Jimak/Kitab Tib MSS 2905

Kitab Tib MSS 1292

Kitab Tib MSS 300

Syair Laksana Kita MSS 2590

\section{Secondary Sources}

Al-Ghazali. 2012. Marriage and Sexuality in Islam. Translated by Madelain Farah. Kuala Lumpur: Islamic Book Trust. Ali, Kecia. 2016. Sexual Ethics and Islam: Feminist Reflections on Qur'an, Hadith, and Jurisprudence. London: Oneworld Publications. Al-Jawziyya, Ibn Qayyim. 1998. Medicine of the Prophet. Translated by Penelope Johnstone. Cambridge: Islamic Texts Society. Andaya, Barbara Watson. 2006. The Flaming Womb: Repositioning Women in Early Modern Southeast Asia. Honolulu: University of Hawaii Press. Azdajic, Dejan. 2016. Longing for the Transcendent: The Role of Love in Islamic Mysticism with special reference to al-Ghazālī and Ibn al-'Arabī". Transformation 33: 99-109. [CrossRef]

Bares, Annie, Stephanie Zellar, Cullen D. Jackson, Daniel F. Keefe, and Francesca Samsel. 2020. Upon Close Reading as a Method for Evaluating Visualisations. Paper presented at IEEE Workshop on Evaluation and Beyond-Methodological Approaches to Visualisation (BELIV), Salt Lake City, UT, USA, October 25-30.

Biernacki, Loriliai. 2006. Sex Talk and Gender Rites: Women and the Tantric Sex Rite. Hindu Studies 10: 185-206. [CrossRef]

Bode, Katherine. 2017. The Equivalence of "Close" and "Distant" Reading; or, toward a New Object for Data-Rich Literary History. Modern Language Quarterly 78: 77-106. [CrossRef]

Bouhdiba, Abdelwahab. 2012. Sexuality in Islam. Translated by Alan Sheridan. London: Saqi Books.

Braginsky, Vladimir. 2004. The Science of Women and the Jewel: The Synthesis of Tantrism and Sufism in a Corpus of Mystical Texts from Aceh. Indonesia and the Malay World 32: 141-75. [CrossRef]

Braginsky, Vladimir. 2017. The Manner of the Prophet_Concealed, Found and Regained. Indonesia and the Malay World 45: 150-291. [CrossRef]

Braginsky, Vladimir. 2019. Through the Optics of Imagination. Indonesia and the Malay World 47: 373-405. [CrossRef] 
Cheah, Boon Kheng. 1993. Power Behind the Throne: The Role of Queens and Court Ladies in Malay History. Journal of the Malaysian Branch of the Royal Asiatic Society 66: 1-21.

Dangler, Jean. 2015. Nonmodern Love and Sex in Ibn Hazm al-Andalusi's Tawq al hamama and Ahmad ibn Yusuf al-Tifashi's Nuzhat al-albab fima la yujad fi kitab. Africa Today 61: 13-25. [CrossRef]

Ding, Choo Ming. 2002. Khatijah Terung dengan Karyanya Perhimpunan Gunawan Bagi Laki-Laki dan Perempuan (Bahagian 1). Jurnal Filologi Melayu 10: 19-33.

Foucault, Michel. 1990. The Use of Pleasure: Volume 2 of the History of Sexuality. New York: Vintage Books.

Franke, Patrick. 2012. Before Scientia Sexualis in Islamic Culture: 'ilm al-bāh between Erotology, Medicine and Pornography. Social Identities 18: 161-73. [CrossRef]

Gallop Teh, Annabel. 1990. Early Malay Printing: An Introduction to the British Library Collections. Journal of the Malaysian Branch of the Royal Asiatic Society 63: 85-124.

Ghandour, Ali. 2017. Lust and Grace: Sex and Eroticism in the Works of Muslim Scholars. Translated by Margarita Giovanni. Hamburg: Editio Gryphus.

Ghanim, David. 2018. The Sexual World of the Arabian Nights. Cambridge: Cambridge University Press.

Hadley, Jeffrey Alan. 2008. Muslims and Matriarchs: Cultural Resilience in Indonesia through Jihad and Colonialism. Ithaca: Cornell University Press.

Harun, Mat Piah. 2014. Ilmu Perkasihan (Seksologi) Melayu Tradisional: Satu Pembicaraan Awal. Kuala Lumpur: Perpustakaan Negara Malaysia, pp. 1-20.

Harun, Mat Piah, and Sobree Naseer. 2019. Seksologi: Ilmu Perkasihan Melayu. Kuala Lumpur: Perpustakaan Negara Malaysia.

Hijjas, Mulaika. 2011. Victorious Wives: The Disguised Heroine in 19th-Century Malay Syair. Singapore: NUS Press.

Hijjas, Mulaika. 2013. Guides for Mrs Nawawi: Two 19th-century Malay Reformist Texts on the Duties of Wives. Indonesia and the Malay World 41: 215-36. [CrossRef]

Hooker, Michael Barry. 1972. Adat Laws in Modern Malaya: Land Tenure, Traditional Government, and Religion. Kuala Lumpur: Oxford University Press.

Jelani, Harun. 2005. Bustan al-Salatin Mutiara Kesufian Untuk Raja-Raja Daripada Nuruddin al-Raniri. Jurnal Filologi Melayu 13: 25-39.

Karim, Wazir-Jahan Begum. 1992. Women and Culture: Between Adat and Islam. Boulder: Westview Press.

Khan, Sher Banu A. L. 2017. Sovereign Women in a Muslim Kingdom: The Sultanahs of Ache, 1641-1699. Singapore: NUS Press.

Khorangy, Alireza, Hanadi Al-Samman, and Michael C. Beard, eds. 2018. The Beloved in Middle Eastern Literatures: The Culture of Love and Languishing. London: I.B. Tauris.

Khuri, Fuad I. 2001. The Body in Islamic Culture. London: Saqi Books.

Liaw, Yock Fang. 2013. A History of Classical Malay Literature. Translated by Razif Bahari, and Harry Aveling. Singapore: ISEAS, Jakarta: Yayasan Pustaka Obor Indonesia.

Lousada, Mike, and Elena Angel. 2011. Tantric Orgasm: Beyond Masters and Johnson. Sexual and Relationship Therapy 26: 389-402. [CrossRef]

Mathers, Powys. 1972. The Book of the Thousand Nights and One Night. 4 vols. Rendered into English form the Literal and Complete French Translation of Dr J. C. Mardrus. New York: St. Martin's Press.

Merguerian, Gayane Karen, and Afsaneh Najmabadi. 1997. Zulaykha and Yusuf: Whose "Best Story"? International Journal of Middle East Studies 29: 485-508. [CrossRef]

Mohd Faizal, Musa, and Tan Beng Hui. 2017. State-Backed Discrimination against Shia Muslims. Critical Asian Studies 7: 308-29.

Muhammad Al-Nafzawi, Muhammad Ibn. 1999. The Perfumed Garden of Sensual Delight. Translated with Introduction and Notes by Jim Colville. New York: Routledge.

Musa, Mohd F. 2021. Transcripts of Gender, Intimacy, and Islam in Southeast Asia: The “Outrageous" Texts of Raja Ali Haji and Khatijah Terung. Religions 12: 219. [CrossRef]

Myrne, Pernilla. 2018a. Pleasing the Beloved: Sex and True Love in a Medieval Arabic Erotic Compendium. In The Beloved in Middle Eastern Literatures: The Culture of Love and Languishing. Edited by Alireza Khorangy, Hanadi Al-Samman and Michael C. Beard. London: I.B. Tauris, pp. 215-36.

Myrne, Pernilla. 2018b. Women and Men in al-Suyuti's Guides to Sex and Marriage. Mamluk Studies Review 21: 47-67.

Myrne, Pernilla. 2019. Slaves for Pleasure in Arabic Sex and Slave Purchase Manual from the Tenth to the Twelfth Centuries. Journal of Global Slavery 4: 196-225. [CrossRef]

Myrne, Pernilla. 2020. Female Sexuality in the Early Medieval Islamic World: Gender and Sex in Arabic Literature. London: I.B. Tauris.

Perpustakaan Negara Malaysia. 1993. Katalog Induk Manuskrip Melayu: Siri Bibliograpfi Manuskrip No. 10. Kuala Lumpur: Pusat Manuskrip Melayu.

Rahman, Fazlur. 1987. Health and Medicine in the Islamic Tradition: Change and Identity. New York: The Crossroad Publishing.

Shaw, Miranda. 1994. Passionate Enlightenment: Women in Tantric Buddhism. Princeton: Princeton University Press.

Skora, Kerry Martin. 2007. Abhinavagupta's Erotic Mysticism: The Reconciliation of Spirit and Flesh. International Journal of Hindu Studies 11: 63-88. [CrossRef]

Smith, Barbara Herrnstein. 2016. What was “Close Reading”?: A Century of Method in Literary Studies. Minnesota Review 87: 57-75. [CrossRef]

Yaghoobi, Claudia. 2016. Yusuf's “Queer" Beauty in Persian Cultural Productions. The Comparatist 40: 245-66. [CrossRef] 